\title{
Area revenue insurance as a risk management instrument in Serbian agriculture
}

\author{
Todor Marković* $\cdot$ Željko Kokot · Stevan Veličković
}

University of Novi Sad, Faculty of Agriculture, Novi Sad, Serbia

\begin{abstract}
Summary: The Republic of Serbia has very favourable opportunities for the development of crop production. Even so, Serbian farmers face many risks. Due to climate change, it is certain that there will be increasing fluctuations in temperature and rainfall, which will increase the production risks. In recent years, due to globalization and market liberalization, price risks have inevitably increased. On this basis, it is clear that the farmer's basic risks are related to the yield level and the price level of agricultural products. One of the external risk management instruments is insurance and there are two main groups of insurance: traditional and index insurance. The application of area-revenue insurance in agriculture, as a type of index insurance is becoming more and more popular in the last few years, especially in developed countries. This model is based on data related to average revenue of particular administrative unit or region and it represents the basis for premium calculation and insurance benefits. In the case of wheat production as one of the most important crops in the region of Kula municipality, the authors describe the methodology of application of the analysed insurance system. The main advantage of this insurance model is that it does not require the damage assessment and their implementation would reduce the negative financial consequences in Serbian agricultural production. In this way, this insurance model can be seen as a significant alternative to conventional insurance, which can increase insured area and number of insured, and trust and confidence in insurance companies would also be restored.

Key words: area revenue, agriculture, index insurance, risk management, Serbia
\end{abstract}

\section{Introduction}

Weather conditions as a risk factor are particularly significant in agricultural production, as they are much more exposed to a number of dangers than other industries. Due to the fact that this production takes place in specific conditions and is largely unprotected, the risk of an adverse event, the consequences of which

\section{Corresponding author:}

todor.markovic@polj.edu.rs

\section{Acknowledgments:}

This study is a part of the project APV 114-451-2180/2016 titled "Cultivation of forage crops in crop rotation in order to increase soil fertility and biodiversity in agro-ecological conditions of Vojvodina", funded by the Provincial Secretariat for Higher Education and Scientific Research of AP Vojvodina and the results of the research are also subsidized by the Ministry of Education, Science and Technological Development of Republic of Serbia, based on the agreement between the Ministry of Education, Science and Technological Development of Republic of Serbia and the Faculty of Agriculture, University of Novi Sad (451-03-68/2020-14/ 200117), on the realization and financing of scientific research in 2020 .

Cite this article:

Marković T., Kokot Ž., Veličković S. (2020). Area revenue insurance as a risk management instrument in Serbian agriculture. Ratar. Povrt., 57 (2), 43-48. can often take catastrophic proportions, increases. Various risk management instruments are used to mitigate and eliminate the consequences of damages, and within them, insurance takes an important place (Marković, 2010).

There are various kinds of insurance models in agriculture depending on what is taken to calculate the sum insured (yield, revenue, gross margin or production costs). If one determines the basis of insurance, different options can be applied, and generally there are two main groups of insurance products: insurance related to damage or loss (traditional insurance), as well as insurance related to various parameters (index insurance). The traditional type of insurance can be further divided into named risk insurance and multiple risk insurance.

Index-based insurance (also called parametric) is a type of protection that does not cover the actual damage caused by the insured event, but agrees in advance that the payment from the insurance will be made after the occurrence of an event that represents an insured risk and is, in fact, the originator which causes payment. Index crop insurance is based on data related to a 
specific administrative unit or region (Marković, 2013), and within it there are three types: on the basis of regional index, on the basis of weather index (weather derivatives), as well as the NDVI index (normal difference vegetation index), which primarily refers to the use of satellites and drones in agricultural insurance.

Insurance based on a regional index is an alternative to traditional named or multiple risk insurance, and as a parameter, this type of insurance takes the average yield or average revenue in a particular region. In the case of a regional yield model, insurance benefits are obtained if the average regional yield is below the expected longterm average yield (Skees et al., 1997), and it is necessary to verify (prove) that the total insurance payment is conditioned to yield changes. This type of insurance was created in the middle of the last century as an alternative to individual yield insurance, with the aim of reducing moral hazard and adverse selection (Halcrow, 1949), but much more attention was paid to it in the 1990s when this model of insurance came again into the focus of scientific interests (Miranda, 1991).

On the other hand, area-revenue insurance is based on the product of average yield and price for a particular region. In other words, a feature of this type of insurance is the use of average revenue per unit area in a particular administrative region (district, municipality, etc.) as a basis for loss coverage (Dismukes et al., 2013).

The condition for the implementation of this concept is the formation of geographic regions, which are homogeneous in terms of climate conditions. The main advantages of regional index insurance are the elimination of adverse selection and moral hazard, as well as the inclusion of lower franchise, higher levels of coverage, and reduction of transaction costs (Hirschauer, Mußhoff, 2008; Wolf, 1998). This assumes that all the farmers of the region (municipality) pay the same insurance premium and in this way the problem of adverse selection is avoided. Also, during the occurrence of the insured event are also compensated in equal amounts (Ebneth, 2003). With this insurance system, several models can be used to determine the amount of the insurance premium, such as the sum of the actuarial fair premiums, which is adjusted to risk and certain administrative and operating costs (Smith, Watts, 2009). A significant advantage of this model compared to the traditional is reflected in the reduction of moral hazard, since individual policy holders have no influence on the amount of realized regional revenue, as well as on the level of compensation (Chambers and Quiggin, 2002).

In addition, the aforementioned insurance model provides farmers to better ensure comprehensive protection against all risks in relation to the certain individual insurances (Schlieper, 1997). Also, insurance based on this model is less susceptible to asymmetric information, and it is not necessary to determine the expected revenue for each individual farm (Deng et al., 2008).
In this paper, authors put emphasis on area-revenue insurance (ARI). This method of insurance provides protection against loss of revenue caused by a decline in production, a reduction in purchase prices or a combination of both factors. If the revenue is lower than the previously determined average revenue for a particular region, compensation will be paid to all insured farmers within that region. This method of insurance is widely used in the US, while it is not yet present on the European continent as well as in our region.

The aim of this study was to explain the importance and role of the area-revenue insurance model from a theoretical point of view and to point out in a practical example in the municipality of Kula the possibilities of applying this insurance system in Serbian agriculture.

\section{Material and Methods}

In order to fulfil the research goal, the data of the Vrbas Agricultural Advisory Service on average wheat yields in the territory of the municipality of Kula over the last five years were analysed. The contracted value of the wheat per unit of yield was taken over from the Novi Sad Product Exchange. In the example of the mentioned municipality, from the perspective of a farmer, a model of area-revenue insurance was presented. Analysis was performed under the hypothetical assumption that the farmer had the opportunity to buy such insurance product from an insurance company operating in the field.

The farmer in the municipality owns 50 hectares of arable land under wheat. Based on the offer of an insurance company, he can conclude a wheat insurance contract with insurer based on the regional revenue. Also, at the same time he has to choose certain parameters that are necessary for this model and these parameters are conditioned itself - coverage level, subsidy factor, protection factor and loss limitation factor.

First, the farmer has the ability to choose the coverage level for the selected crop (type and method of production), which is used to calculate trigger revenue and it is used to determine whether it has suffered any loss in production (this parameter may range from $70-95 \%$ ). An appropriate subsidy factor is determined for the selected coverage level, depending on whether the natural (yield) or valuable success indicator (revenue) is taken as the regional index. Also, the farmer can choose the protection factor that ranges from $80-120 \%$ (unless otherwise stated in specific provisions), and this factor enables producers to buy protection that is below, above, or equal to the average of the region (municipality) which represents the expected revenue. On the other hand, the farmer can choose different protection factors for the selected crop (type and method of production), and his choice 
directly affects the amount of insurance premium. The premium rate is based on the so-called volatility factor, that is, indicates the degree of variation series of trading prices over time as measured by standard deviation (Schnitkey, 2014).

At the beginning of the insurance period, based on municipal data, the average wheat yield in the previous period (usually a period of five years) is determined, as well as the projected price, based on which the expected wheat revenue in a given municipality can be calculated. On the other hand, at the end of the insurance period, the average municipal wheat yield and its harvest price are published and based on this the final county wheat revenue. This insurance model (ARI) uses both projected and harvested prices to determine if there is a loss in value during the production process. The harvest price is the price determined in accordance with the "Stock Exchange Price Regulation" (CEPP) used to determine the revenue of a particular region in the USA (www.farmfutures.com). The price that is higher at a given moment is always taken to calculate in this model. The projected and harvested prices are determined from the average contracted futures price given by the competent chamber of commerce over a period of time, referred to as the "discovery" period. Assuming a lower final county revenue than the predefined trigger revenue, a simulated application of the analysed insurance system is performed, the following parameters are calculated, which, with some adjustments by the authors, were taken from ARMtech Insurance Services (www.armt.com):

The sum of insurance per hectare $\left(S_{v e}\right)$ is the product of the expected municipal (county) yield $\left(E_{d g}\right)$, the projected protection price $\left(P_{s p}\right)$ and the protection factor $\left(F_{s}\right)$ :

$$
S_{v e}=E_{d g} \cdot P_{s p} \cdot F_{S}
$$

Policy protection or total insurance sum $\left(\sum S_{v}\right)$ is calculated as the product of insurance sum per hectare $\left(S_{v e}\right)$ and area in hectares $\left(F_{v}\right)$ :

$$
\sum S_{v}=S_{v e} \cdot F_{v}
$$

Total premium $\left(\Sigma K_{v}\right)$ is calculated as the product of the total sum of insurance or policy protection $\left(V_{s}\right)$ and the premium rate or selected volatility factor $\left(K_{f}\right)$ :

$$
\sum K_{v}=V_{s} \cdot K_{f}
$$

Subsidy amount $\left(\Sigma Z_{v}\right)$ is obtained by multiplying the total insurance premium $\left(\Sigma K_{\imath}\right)$ and the subsidy factor $\left(F_{\vartheta}\right)$ :

$$
\sum Z_{v}=\sum K_{v} \cdot F_{Z}
$$

Producer premium $\left(\Sigma K_{l}\right)$ represents the difference between the total insurance premium $\left(\Sigma K_{v}\right)$ and the amount of subsidy $\left(\sum Z_{v}\right)$ :

$$
\sum K_{l}=\sum K_{v}-\sum Z_{v}
$$

The producer premium per unit area $\left(K_{l e}\right)$ is calculated by dividing the total amount of the producer premium $\left(\Sigma K_{l}\right)$ by the area in hectares $\left(F_{v}\right)$ :

$$
K_{l e}=\frac{\sum K_{l}}{F_{v}}
$$

Final policy protection or the final insurance sum $\left(\sum S_{v j}\right)$ is the product of expected municipal (county) yield $\left(E_{d g}\right)$, projected or harvested price $\left(P_{p}\right)$, protection factor $\left(\mathrm{F}_{\mathrm{s}}\right)$ and acreage $\left(\mathrm{F}_{v}\right)$ :

$$
\sum S_{v f}=E_{d g} \cdot P_{p} \cdot F_{S} \cdot F_{v}
$$

Final county revenue $\left(R_{g}\right)$ is obtained by multiplying the average municipal (county) yield at the end of the insurance period $\left(E_{e g}\right)$ and the harvested price at the end of the insurance period $\left(P_{p}\right)$ :

$$
R_{g}=E_{e g} \cdot P_{p}
$$

Trigger revenue $\left(R_{g n g}\right)$ is calculated as the product of expected municipal (county) yield $\left(E_{d g}\right)$, harvested or projected price $\left(P_{p}\right)$ and coverage level $\left(G_{d}\right)$ :

$$
R_{g n g}=E_{d g} \cdot P_{p} \cdot G_{d}
$$

Payment factor $\left(F_{p}\right)$ represents the quotient of the difference between the trigger revenue $\left(R_{g n g}\right)$ and the final county revenue $\left(R_{g}\right)$ in the numerator, and the difference between the trigger revenue $\left(R_{g n g}\right)$, and the product of expected municipal (county) yield $\left(E_{d g}\right)$, harvested or projected price $\left(P_{p}\right)$ and loss limitation factor $\left(F_{v b}\right)$ in the denominator, expressed as the following formula:

$$
F_{p}=\frac{R_{g n g}-R_{g}}{\left(R_{g n g}-\left(E_{d g} \cdot P_{p} \cdot F_{v b}\right)\right)}
$$

Indemnity $\left(\Sigma A_{v}\right)$ represents the product of the final policy protection or final insurance amount $\left(\Sigma V_{s f}\right)$ and the payment factor $\left(F_{p}\right)$ :

$$
\sum A_{v}=\sum V_{s f} \cdot F_{p}
$$

On the other hand, the indemnity per area unit $\left(A_{\nu e}\right)$ can be obtained as a quotient of the indemnity $\left(\sum A_{v}\right)$ and the area in hectares $\left(F_{v}\right)$ :

$$
A_{v e}=\frac{\sum A_{v}}{F_{v}}
$$


Based on the above calculations, the total insurance sum (policy protection), insurance costs in the form of total and producer insurance premiums (taking into account state subsidies for insurance premiums), as well as the total value of losses in wheat production (payment factor), which can be offset by calculating the appropriate indemnity from the analysed insurance model.

\section{Research results}

Area-revenue insurance provides protection for farmers' incomes, both due to reduced yields and due to the decrease of agricultural products prices. Due to the fact that the amount of insurance is adjusted to market prices, this type of insurance is an effective risk management measure and a significant means of supporting farmers, especially in times when grain prices are high or rising (Dismukes et al., 2013). This insurance model is only available in the certain regions of USA for the following crops: wheat, corn, soybean, barley, cotton, rice, peanuts and sorghum (www.amtrustag.com). This insurance model (ARI) activates the indemnity if the final county revenue is less than the trigger revenue chosen by the producer itself. Therefore, the trigger revenue and final county revenue are based solely on the performance of the entire region in terms of revenue and not on what has happened on the individual farm.
The following is an example of using area-revenue insurance model in the municipality of Kula, and the following assumptions are taken into account: An agricultural producer from the municipality of Kula is engaged in the production of wheat on 50 hectares, which he owns. He opted for this type of insurance because of the risk of price reduction, but also because of the lower yield in the previous dry year. According to the data of the Agricultural Advisory Service of Vrbas, the expected average wheat yield in the territory of the observed municipality is $4.5 \mathrm{t} / \mathrm{ha}$, while the Novi Sad Product Exchange announced that the expected (projected) price of wheat in the harvest period in 2018 amount to $16,000 \mathrm{RSD} / \mathrm{t}$, and on that basis the average final county revenue in the municipality of Kula is 72,000 RSD/ha.

Starting from formula (1), assuming a protection factor of $110 \%$, the insurance sum per hectare is RSD 79,200 . Based on this information, multiplying the given amount by the number of hectares under wheat owned by the farmer (Formula 2) it is given a policy protection (total insurance sum) in the amount of RSD 3,960,000 (Table 1).

As is known, the insurance contractor must pay the insurer an insurance premium for his services. Taking into account that in the specific example, the volatility factor, i.e. the premium rate is $2 \%$, the total premium, based on the formula (3), is obtained by multiplying the

Table 1. Calculating the indemnity based on the Area-Revenue Insurance

\begin{tabular}{|c|c|c|c|}
\hline Parameters & Unit & Unit of measure & Amount \\
\hline Expected county yield & $\mathrm{E}_{\mathrm{dg}}$ & $\mathrm{t} / \mathrm{ha}$ & 4.5 \\
\hline Projected protection price & $\mathrm{P}_{\mathrm{sp}}$ & $\mathrm{RSD} / \mathrm{t}$ & 16,000 \\
\hline Protection factor & $\mathrm{F}_{\mathrm{s}}$ & $\%$ & 110 \\
\hline Sum of insurance per unit area & $S_{v e}$ & $\mathrm{RSD} / \mathrm{ha}$ & 79,200 \\
\hline Surface area & $\mathrm{F}_{\mathrm{v}}$ & ha & 50 \\
\hline Policy protection - total insurance sum & $\Sigma S_{v}$ & RSD & $3,960,000$ \\
\hline Volatility factor - premium rate & $\mathrm{F}_{\mathrm{v}}$ & $\%$ & 2 \\
\hline Total premium & $\Sigma K_{v}$ & RSD & 79,200 \\
\hline Subsidy factor & $\mathrm{F}_{\mathrm{z}}$ & $\%$ & 0.5 \\
\hline Subsidy amount & $\Sigma Z_{v}$ & RSD & 39,600 \\
\hline Producer premium - premium charged to farmers & $\Sigma K_{l}$ & RSD & 39,600 \\
\hline Producer premium per unit area & $K_{l e}$ & $\mathrm{RSD} / \mathrm{ha}$ & 792 \\
\hline Harvest price & $\mathrm{P}_{\mathrm{p}}$ & $\mathrm{RSD} / \mathrm{t}$ & 18,000 \\
\hline Final policy protection - final insurance sum & $\Sigma S_{v f}$ & RSD & $4,455,000$ \\
\hline Average county yield at the end of the insurance period & $E_{e g}$ & $\mathrm{t} / \mathrm{ha}$ & 4 \\
\hline Final county revenue & $R_{g}$ & $\mathrm{RSD} / \mathrm{ha}$ & 72,000 \\
\hline Coverage level & $G_{d}$ & $\%$ & 95 \\
\hline Trigger revenue & $\mathrm{R}_{g n g}$ & $\mathrm{RSD} / \mathrm{ha}$ & 76,950 \\
\hline Loss limitation factor & $F_{v b}$ & $\%$ & 15 \\
\hline Payment factor & $F_{p}$ & $\%$ & 7.6 \\
\hline Indemnity & $\Sigma A_{v}$ & RSD & 340,313 \\
\hline Indemnity per unit area & $A_{v e}$ & $\mathrm{RSD} / \mathrm{ha}$ & 6,806 \\
\hline
\end{tabular}

Source: Author's calculations 
policy protection by the volatility factor and it amounts to RSD 79,200. However, the payment of crop insurance premiums is also facilitated by government subsidies each year. The state returns to the registered agricultural holdings a portion of the insurance premium paid, as specified by the relevant regulations issued by the Ministry of Agriculture, Forestry and Water Management. If it is assumed that the subsidy factor for the $95 \%$ coverage level is $50 \%$ for revenue protection, then the subsidy that the government will repay to the farmer is $39,600 \mathrm{RSD}$, according to formula (4). This information means that the farmer will actually pay the so-called producer's premium, which is also RSD 39,600, using formula (5). The amount of premium paid by the producer per hectare (producer premium per unit area) using from formula (6) is 792 RSD/ha (Table 1).

At the end of the insurance period on $01 / 08 / 2018$, the Novi Sad Product Exchange announced that the wheat price was $18,000 \mathrm{RSD} / \mathrm{t}$, while the Vrbas Agricultural Advisory Service announced that the average wheat yield at the level of the municipality of Kula was $4 \mathrm{t} / \mathrm{ha}$. Since all the information related to the projected and harvested prices are known, the final policy protection (final insurance sum) is calculated based on formula (7), which amounts to RSD 9,504,000. On the other hand, the final county revenue in the municipality of Kula, after the announcement of wheat price and wheat average yield, will be $72,000 \mathrm{RSD} /$ ha (according to formula 8). Assuming that the farmer has previously selected a coverage level of $95 \%$ for calculating the trigger revenue, the trigger revenue, on which the producer will receive indemnity, is calculated according to formula (9) and amounts to 76,950 RSD/ ha (Table 1).

In order to calculate the indemnity that a farmer will receive due to the fact that the final county revenue is lower than the trigger revenue, previous should be calculated so called payment factor, and according to formula (10) it would be $7.6 \%$, noting that the loss limitation factor chosen by the farmer is at the level of $15 \%$. Finally, the indemnity that the farmer would receive is calculated on the basis of formula (11) and amounts to RSD 340,313. The amount of indemnity per unit area, using formula (12), is 6,806 RSD/ha (Table 1).

Based on this model example, it is clear that the basic assumption for the implementation of arearevenue insurance in Serbia is the proper formation of certain geographical units - (micro) regions (Kula Municipality is taken as an example here), which should be homogeneous in terms of weather parameters. Serbian farmers are given more comprehensive protection with this insurance model than traditional insurance, since in addition to yield insurance, the product price is also ensured. They can also define the height of individual parameters of the selected model (coverage level, subsidy factor, volatility factor, loss limitation factor) which gives them certain predictability in production and the possibility of compensating them for possible failure to meet the predefined revenue. With the traditional insurance model, farmers can create the planned yields and the planned product prices, in which case they depend on the average county yield at the end of the insurance period and the projected or harvested product price. This excludes the existence of moral hazard, since they do not have the ability to influence the amount of final county revenue, as well as the amount of insurance indemnity. On the other hand, all farmers pay the same insurance premium, thereby excluding adverse selection.

The trigger revenue (guaranteed revenue) and the final policy protection are based solely on the performance of the whole municipality in terms of the amount of revenue and not on the basis of what happened on the farm of the single agricultural producer. In other words, a Serbian farmer may record a loss on his farm but will not receive compensation if the entire municipality has not recorded a loss. On the other hand, if it happens that the final county revenue was lower than the trigger revenue, the agricultural producer would receive compensation even if he did not record a loss on his farm.

\section{Conclusion}

The adverse weather conditions that occur in various forms around the world can have catastrophic consequences for agricultural production, so different types of insurance, both crops as well as livestock, are imposed as a necessity in today's production environment. Compensation for damages by the payment of adequate indemnity should enable farmers to recover the financial position they were in before the insured event occurred. Today, there are a great number of insurance systems in the world, among which area-revenue insurance as a type of index (parametric) insurance is especially emphasized. This type of insurance brings numerous benefits for farmers in the agricultural regions of the United States of America (no moral hazard, no negative selection, no damage assessment, higher coverage and higher loss limitation). On the other hand, there is still no widespread usage in Europe, while it still does not exist in Serbia. Based on the previous example, it is clear that all farmers who protect their crops in this way (and if the final county revenue is lower than the trigger revenue) receive appropriate compensation (6,806 $\mathrm{RSD} / \mathrm{ha}$ ). What they have to pay the insurer is an insurance premium (792 RSD/ha) as the price for the assumed production and price risks. However, in spite of the fact that they can choose for themselves certain conditions necessary for this model of insurance (coverage level, protection factor, subsidy factor, loss limitation factor), the specificity of this model is 
reflected in the fact that the final county revenue is based solely on the performance of the whole municipality by looking at the amount of revenue, not based on what happened on individual farms. In this case, it may be that the agricultural producer may record a loss on his farm, but he will not receive compensation if the whole municipality does not record the loss. If it happens that the final county revenue was lower than the average (trigger revenue), the agricultural producer will be compensated even if he has not recorded a loss on his farm.

It is certain that the presented insurance model can be a complement to the existing risk management instruments, and because of these advantages, it can have a positive effect on the increase of the insured areas, as well as, on the strengthening of trust between insurers and farmers.

\section{References}

AmTrust Financial (www.amtrustag.com), accessed 26 January 2020. ARMtech Insurance Services (www.armt.com), accessed 22 January 2020.

Chambers, R.G., Quiggin, J. (2002). Optimal Producer Behavior in the Presence of Area-Yield Crop Insurance. American Journal of Agricultural Economics, 84(2): 320-334.

Deng, X., Barnett, B.J., Hoogenboom, G., Yu, Y., Garcia, A. (2008) Alternative Crop Insurance Indexes. Journal of Agricultural and Applied Economics, 40(1): 223-237.

Dismukes, R., Coble, K., Miller, C., O’Donoghue, E. (2013). The effects of area-based revenue protection on producers' choices of farm-level revenue insurance. Agricultural and Applied Economics Association 2013 Annual Meeting, Washington, DC, USA.

Ebneth, O.J. (2003). Mehrgefahrenversicherung als Risiko-ManagementInstrument für die deutsche Landwirtschaft. Master's thesis, Fakultät für Agrarwissenschaften, Göttingen, Deutschland.

Farm Futures (www.farmfutures.com), accessed 16 January 2020

Halcrow, H.G. (1949). Actuarial Structures for Crop Insurance. Journal of Farm Economics, 31: 418-443.

Hirschauer, N., Musshoff, O. (2008). Risikomanagementinstrumente im Vergleich: Sollte man landwirtschaftliche Ernteversicherungen subventionieren? - Gute alte Argumente in einem neuen Streit, Vortrag anlässlich der 48. Jabrestagung der GEWISOL A „Risiken in der Agrar und Ernährungswirtschaft und Ibre Bewältigung", 24.-26. September, Bonn, Deutschaland.

Marković, T. (2010). Weather risk management in plant production. Annals of Agronomy, 34(1): 23-31.

Marković, T. (2013). Weather Derivatives and Risk Management in Agriculture. University of Novi Sad, Faculty in Agriculture, Novi Sad, Serbia.

Miranda, M.J. (1991). Area-Yield Crop Insurance Reconsidered. American Journal of Agricultural Economics, 73: 233-242.

Schlieper, P. (1997). Ertragsausfallversicherung und Intensität pflan₹licher Produktion, Wiesbaden.

Schnitkey, G. (2014). Area Risk Protection Insurance Policy: Comparison to Group Plans. Department of Agricultural and Consumer Economics, University of Illinois, USA.

Skees, J.R., Black, J.R., Barnett, B.J. (1997). Designing and rating an area yield crop insurance contract. American Journal of Agricultural Economics, 79: 430-438.

Smith, H.V., Watts, M. (2009). Index Based Agricultural Insurance in Developing Countries: Feasibility, Scalability and Sustainability. Monograph published electronically by the Bill and Melinda Gates Foundation.

Wolf, T. (1998). Ernteversicherungssysteme als Risk-Management Instrument für den Landwirt und ibr Einsatz im Rabmen der US-Agrarpolitik. Master's thesis, München-Weihenstephan, Deutschland.

\section{Osiguranje na bazi regionalne vrednosti proizvodnje kao instrument za upravljanje rizicima u srpskoj poljoprivredi}

\section{Todor Marković · Željko Kokot · Stevan Veličković}

Sažetak: Republika Srbija ima veoma povoljne mogućnosti za razvoj ratarske proizvodnje. Uprkos tome, srpski poljoprivrednici se suočavaju sa brojnim rizicima. Usled klimatskih promena, izvesno je da će dolaziti do sve većih kolebanja temperature, kao i izraženih oscilacija u količini padavina, što će uticati na povećanje proizvodnih rizika u poljoprivredi. Poslednjih godina, zbog globalizacije i liberalizacije tržišta, neminovno dolazi do porasta cenovnih rizika. Na osnovu toga, jasno je da se osnovni rizici koji padaju na teret vezuju za visinu prinosa, kao i visinu cena poljoprivrednih proizvoda. Jedan od eksternih instrumenata za upravljanje rizicima predstavlja osiguranje, a razlikuju se dve osnovne grupe osiguranja: tradicionalno i indeksno osiguranje. Primena modela baziranog na regionalnoj vrednosti proizvodnje, kao vrsti indeksnog osiguranja, postaje sve popularnija u poslednjih nekoliko godina, posebno u razvijenim zemljama. Ovaj model zasnovan je na podacima koji se odnose na prosečnu vrednost proizvodnje određene administrativne jedinice ili regiona i predstavlja osnovu za obračun premije i naknade iz osiguranja. $\mathrm{Na}$ primeru proizvodnje pšenice, kao jednog od najvažnijih useva u regionu opštine Kula, autori prikazuju metodologiju primene analiziranog sistema osiguranja. Osnovna prednost ovog modela osiguranja je u tome što ne zahteva procenu štete i njegovom primenom bi se smanjile negativne finansijske posledice u srpskoj poljoprivrednoj proizvodnji. Navedeni model osiguranja može se posmatrati kao značajna alternativa tradicionalnom osiguranju, što može pozitivno uticati na povećanje osiguranih površina, kao i broja osiguranika, a povratilo bi se i poverenje u osiguravajuće kompanije.

Ključne reči: indeksno osiguranje, poljoprivreda, regionalna vrednost proizvodnje, Srbija, upravljanje rizicima 